\title{
前縦隔を経由する永久気管瘻造設手術
}

*村上 泰 向井 将 浅岡 一之
佐藤 学 大築 淳一 岡本 亮二

\section{Tracheostoma through the Anterior Mediastinum}

\author{
Yasushi Murakami, M.D., Susumu Mukai, M.D., Kazuyuki Asaoka, M.D., \\ Manabu Sato, M.D. Junichi Otsuki, M.D., and Ryoji Okamoto, M,D. \\ Dept. of Otolaryngology, School of Medicine, Keio University
}

\begin{abstract}
Advanced cancer in the cervical esophagus or in the cervical trachea and recurrent cancer in the lower neck can be controlled and cured if extensive radical surgery is performed, in which resection of the cervical trachea is combined with relocatin of the trachea in the uppr chest wall through the anterior mediastinum. Excision of the upper part of sterum and the head of the clavicle and sliding the skin of anterior chest wall down into the mediasfinum are most responsible for a safer anastomosis of the tracheal stump. Wound dehiscence and crust formation in the trachea can be avoidable by an intensive post-operative case. Indications and detailed surgical procedure were described in this paper with some care reports.
\end{abstract}

永久気管瘦 (tracheostoma) は, 喉頭全摘除術に際 して前頸部皮膚へ造設されるのが一般的であるが，後 述するような理由により，頸部気管を広籁囲に切除し なくてはならない場合には，前頸部下端皮膚への縫合 は困難となり，胸骨を削除して前縦隔を経由して気管 断端を引出し，前胸壁皮膚へ縫合する mediastinal, tracheostoma を造設しなくてはならなくなる。

胸骨柄および鎖骨骨頭を削除して前縦隔へ達する手 術ルートは，すでに古く1800年代に Bardenheuer ${ }^{1}$ に よってなされ，その後気管腫瘍や甲状腺腫瘍の下方浸 潤に対する根治的切除を目的として, 胸骨を夕テ切開 して前縌隔を廊清する術式が Waddell' ${ }^{2}$, Sisson ${ }^{3)}$, Pressman4)，らによって開発されてから比較的ポピュ ラーな領域となり，頭頸部腫瘍を取扱らわれわれにと っても必修の術式となりつつある。頸部永久気管瘦で は，術後管理の方法もすでに確立されているし，合併 症も致命的なものはなく，たとえ狭窄を来しても Montgomery の方法(5),6) どによって開大を計ること も可能であるのに対して, 前胸壁へ縫合する本術式で

*慶応義塾大学医学部耳鼻咽喉科 （主任：斎藤成司教授）
は, これ以上気管を切除して狭窄に対処することも不 可能であり, 縫合不全により感染を来せば緃隔炎とな って致命的ともなりうるものであって, 失敗は許され ない。その意味でも基本的術式に精通しておくことが 必須である。われわれも今日までに15症例に本術式を 行なった。最初のころ行なった 4 症例と最近経験した 1 例では, 前綎隔内一の浸潤がつよく腫瘍の根治が不 可能であったため，いずれも予後不良であったが7， 他の10例は経過良好で，いずれも再発や狭窄を来すこ となく生存しており，4例はすでに 3 年治療に成功し た。本論文の目的は, 本術式の詳細を述べ, 術後管理 などの付随する問題についても検討することである。

\section{〔1]本手術法の適応}

本法は頸部気管を広範囲に切除した場合の永久気管 霋造設法であり，気管断端が胸骨上縁から 1 横指上の レベルより下方に位置する場合には, 頸部皮盧へ縫合 しても緊張がつよくなって縫合不全や狭窄を来すこと になるため全て本法の適応となる。それらをまとめる と, 
(A) 一次手術として行なうもの

1. 喉頭癌で声門下進展著しいもの

2. 甲状腺癌で気管切除を要するもの

3. 下咽頭・䁰部食道癌で気管切除を要するもの

4. 気管腫瘍

5. 外傷その他の理由で気管切除を要するもの

(B) 二次手術として行ならもの

1. stomal recurrence

2. stomal stenosis で Montgomery 手術 の行 なえないもの，

などがその適応となる。下咽頭・頸部食道癌で臨床 的に気管壁まで浸潤のある進展癌は比較的少ないが, 甲状腺へ浸潤していたり，傍気管リンパ節の固着して いる症例や，非開胸食道全抜去手術の適応となる症例 では，腫瘍切除の radicality の面でも気管切除を行な った方が有利であるし，手技上も胸骨上方が切除して あると縦隔内での用指剝離がやり易いといら利点があ るため，最近ではこのような症例には全例に本法を用 いることにして良い結果を得ている。

\section{〔2〕術式及び術後管理}

\section{A 皮切について}

頙部手術に続いて一次的に行なう場合には，頸部の U字型皮切の最下端から前胸壁正中に第 4 肋間レベル まで皮切をおく。最初に気管切開を行なら場合には, U字型の最下端の皮切線を利用して行なえばよいし， すでに気管切開がしてある症例では，その周井の皮膚 を含めて切除するようにデザインし，頸部永久気管瘦 の作ってある症例では, 前回の手術時の皮切線に合わ せてほぼT型皮切をおけばよい（図1 A, B, )。新しく 造設する気管瘦はこのタテ皮切線のほぼ中央に位置す ることになる。本法を成功させる要点の一つは, 骨を 充分削除して前胸壁皮膚を縦隔内一落込ませることに より，気管断端との縫合部を緊張させないことであ る。そのためには，気管を引出すのに必要なだけの小 範囲な骨削除では意味がないし，前胸壁皮膚の undermining も必須となり, 胸骨外側で肋間庄貫通して出 て来る内乳動脈の antericr perfcrat $:$ r は切断される ことになる。この血管は DP 皮弁法の栄養血管として 利用価值の高いものであるだけに，特に頸部皮虐久損 を修復せねばならぬような症例では，すくなくとも一 側ではこれらを保存するよう注意する。縫合部の過緊 張は禁物で, 気管へ縫合する部分の皮膚は約 $1 \mathrm{~cm}$ 径に 切除トリミングするのがよい。意外にのびて大きな気 管孔ができ上る。この部分の皮虐は，全周を約 $2 \mathrm{~mm}$
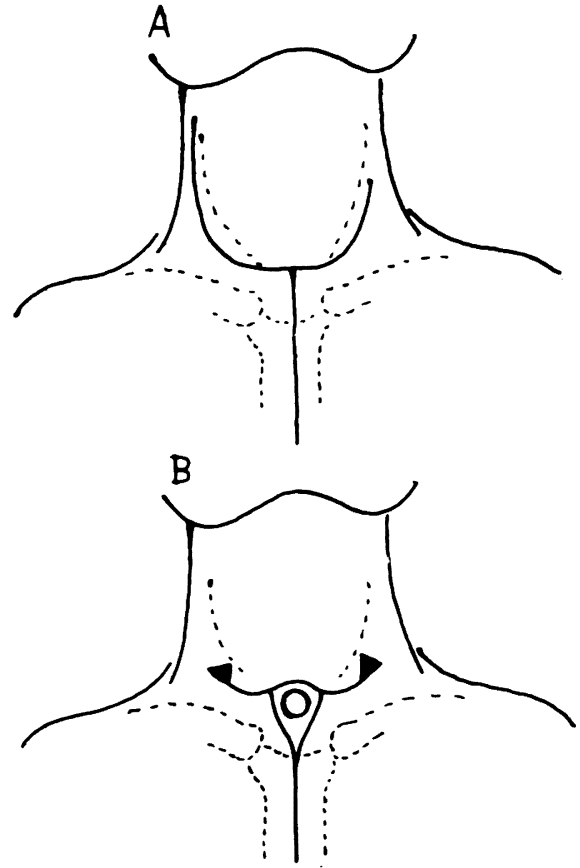

図1皮切線。頸部手術に続けて行なう場合はA。 すでに stomaのある例ではB。

幅に皮膚層だけ薄く切除しておく,この操作により気 管粘膜が外方へ引き出された形で仕上ることになって 具合がよい。

\section{B 軟組織の処理}

頸部では浅頸筋膜レベル，前胸壁では大胸管膜に沿 って両側皮虐を翻転し，鎖骨骨頭および胸骨を露出さ せる。胸鎖乳笑筋の sternal head は付着部で切離, claviclar head も骨頭に付着する部分を切離する。鎖 骨間勒帯は正中て鋭利に切離して胸骨柄上縁に達し， ここから胸骨裏面に沿って示指を挿入し，左右に動か しながら周囲軟組織を充分圧排する。繸隔内だけでな く，特に上方で鎖骨の裏面を広く開放しておくことが 大切である。縦隔内で損傷を受ける可能性のあるもの は両側胸膜および大血管群, 特に上方では腕頭動静脈 でありこれらを指の腹で押しわける感じをつかむこ とが大切で, 剝離子などを挿入すると胸膜損傷の危険 がつよくなる。皮䖉および筋組織への小血管や胸骨上 縁での最下甲状腺静脈群などはかるく電気凝固しなが らてきぱきと術をすすめる。

\section{C 胸骨および鎖骨の部分切除}

骨の切除範囲を図 2 に示す。広く開放された鎖骨の 下面から，幅約 $3 \mathrm{~cm}$ のへラ鈎を適度に折曲げて，骨 の裏面へ密着させながら挿入し，先端が正中に位置す 


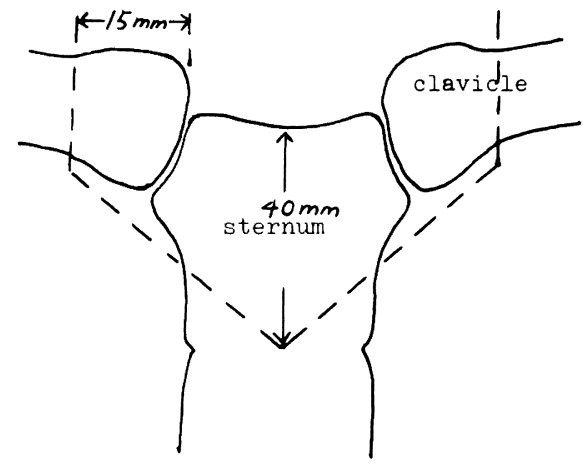

図 2 鎖骨および胸骨の切除範囲

るようにして助手に保持させる。これに向って切りつ ける要領で, ストライカーを用いて一気に切断し, 両 側鎖骨骨頭および胸骨柄を三角型の一塊として切除す る。さらに, 左手の示指で胸膜を含む軟組織を下外方 一圧排しながら，大型のリュールで骨を鉗除してゅ き，尖鋭なところを残さ奴に加減しながら全体と してU字型に削除する。出血は吸引しながらここまで 一気に行なって，ここで bone wax を奴けて止血 する。この操作の間, 不用意に加圧して胸膜が術野に はみ出して来ることのないよう, 麻酔医に協力を求め る必要がある。

\section{D 前縌隔および気管の処理}

頸部気管前壁で二層の頸筋膜内に含まれる軟組織を 正中で離断しながら下方へ向って别離してゆく。細い 静脈から少量の出血をみるだけで, 気管前方を左上方 一横走する左腕頭静脈まで容易に達することができ る。ほとんどが脂肪織で, 萎縮した胸腺組織も含まれ ていてそこへゆく小血管が認められる。前縌隔廊清を 行なら必要のない症例では, これらを切除する必要は なく, きわめて薄い線維性被膜に被われた脂肪性結合 織を左右に分離してゆくだけで，右腕頭動静脈および 気管をなるべく下方をで露出させるよう心掛ける。以 前に䋛隔内まで操作してある症例で線維性療着の著し 、場合には，大血管損傷の危険がつよく，術野で充分 確認しながら少しつうつ剥離してゆく(図 3 )。横走する 左腕頭静脈より 1 横指上方 (症例に応じて可能な限り 上方で）で，断端面積が広くなるように斜めに気管を 切断する。ここから細い(No. 28)チューブを再挿入し て麻酔を続けるが，分岐部まで $4 \sim 7 \mathrm{~cm}$ と短いので 片肺麻酔とならぬよう注意を要する。バブコック鉗子 をさし込んで気管断端を引上げながら全周を約 $3 \mathrm{~cm}$ 下方まで剥離する。尖鋭な小剪刀を用いて気管粘膜を 剝離しつつ軟骨リングを切除する。症例によってはさ

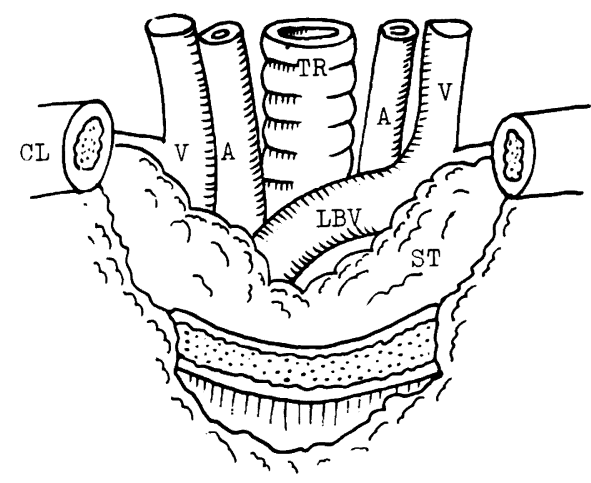

図 3 縦隔内の所見

TR：気管

A : 総頸動脈

$\mathrm{V}$ : 内頸静脈

LBV：左腕頭静脈

ST： 脈脂肪性結合織

CL： 鎖骨断端
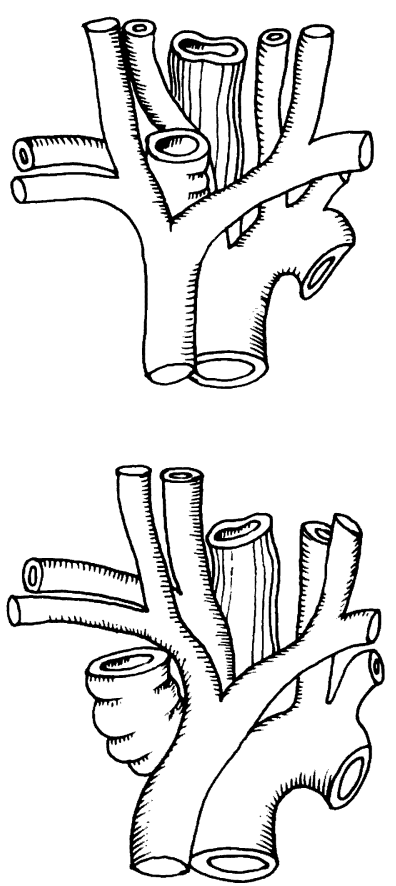

図 4 気管切除の程度により, 腕頭動脈をくぐら せて引出すか(上), さらに腕頭静脈をもく ぐらせることがある(下)。

らに 1 横指下方まで気管切除を要することもあり，そ の場合には断端をそのまま引出すのに無理があり, 右 側で腕頭動脈をくぐらせるか，さらに右腕頭静脈をも 
くぐらせて引出すことになる(図 4)。この操作によっ てもやはり断端は正中一位置させて縫合する。気管壁 と大血管が密着することになり, 呼吸性運動によって 血管壁へ機械的侵熟がおよぶことを危険視するむきも あるが，腫瘍の取残しがないかぎり問題はない。術 後, 気管孔から観察すると, 明瞭な搏動がみられ, 圧 排されてやや気管腔が狭小となるが，これも臨床上全

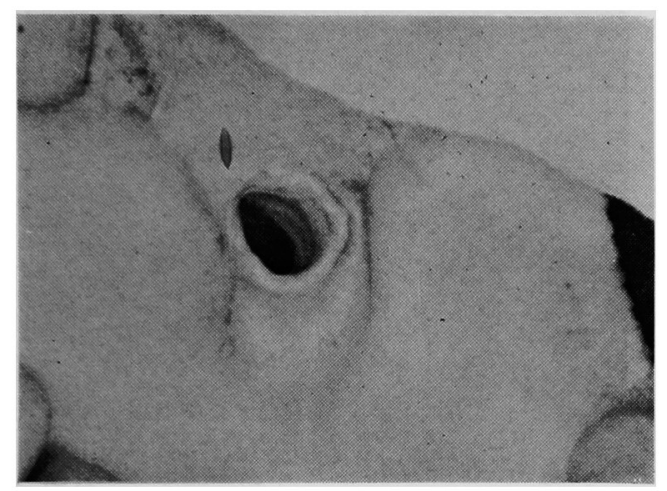

図 5 腕頭動脈をくぐらせて作った気管孔。血管に圧 排された所見がみられる。

く問題とならない(図 5 )。

\section{E 気管皮膚縫合}

気管断端と前胸壁皮膚の縫合は二層に行なら。まず 4-0 chrcmic cat gut を用い, 皮下組織(皮膚層は 2 $\mathrm{mm}$ 幅に切除してある) と軟骨リングを約 $3 \mathrm{~mm}$ 間隔 で縫合する。バブコック鉗子で気管を引上げて減張し ながら，まず全周へ采をかけておいてから，助手と同 時に結禁してゆくのがよい。結紫が下方へゆくよう禾 をかける。気管後壁では粘膜下組織へ釆を通す。次に 4-0 Sigma を用い，粘膜と皮膚をゆるく密に縫合する (図6)。この方法によると, 気管粘膜が前胸壁面へや やはみ出す形で仕上り, 術後管理も容易であるし狭窄 を来すこともなく具合がよい。

\section{F 気管カニューレ}

頸部手術と同時に行なったものでは頸部術創に持続 吸引チューブを入れる他にはドレナージの必要はな い。頸部気管孔狭窄に対して本術式のみを行なった場 合には, 皮切下端に細いフィルムドレーンを一本入れ ておく。頸部気管孔のあった部分の皮䖉は切除して左 右をそのまま寄せればよいが，T字皮切の両端は三角 形に切除して dcg ear をさける必要がある（図 1 B)。

低圧カフ付軟性樹脂製カニューレ（Lanz または Portex）を挿入固定して術を終るが，カニューレの根 元にバラマイシン軟熟を浸ませたガーゼをゆるく巻き
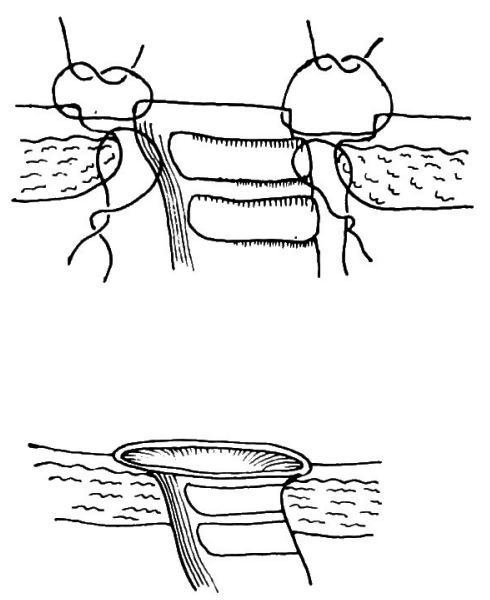

図 6 気管皮膚縫合法（上）と 完成した気管孔（下）。

つけ，これによって前胸壁皮膚を縦隔内に生じた死腔 一押込むようにするのがよい。約一週間カニューレ交 換時にこの操作をくり返す。

術終了後直ちに胸部レ線ポータブルを施行し, 胸膜 損傷による気胸のないことを確認しておく。

$\mathrm{G}$ 術後管理の要点

術後は高湿度酸素テント内に収容する。術後24時間 は持続的に超音波ネブライザーを施行する。気管が極 端に短かくなるために，それだけ加湿機能も低下して いて，胸骨周辺の疼痛によって咳濑による分泌物喀出 の能力も低下しているので，気管孔および気管内に痂 疲形成の起こる危険があるためである。気道確保の意 味ではカニューレを入れておく必要はないが, 前胸壁 皮膚を押込んだ位置に固定するため，毎日交換しなが ら一週間は入れておく必要がある。抜糸は一週後に行 ならが，それ以後も気管孔にバラマイシン軟塾を塗布 して痂疲形成を妨止する。必要に応じビソルボン・ア レベールなどの適下により気管内洗涤を行なう。緹隔 炎を合併しないよう抗生剤投与は必須であり，頚部術 創からの分泌物が流入せぬよう, 頸部のドレナージは $7 \sim 10$ 日閒入れておくのがよい。術後 $2 \sim 3$ 日で歩行 可能となり，骨欠損による機能障害も軽微である。同 時に行なら腫瘍根治手術の種類にもよるが, 通常われ われは術後数日間 $\mathrm{PO}_{2}, \mathrm{PCO}_{2}$, 電解質バランスについ て定時的にチェックしているが, 食道全抜去などに際 して一部胸膜の損傷された例や, 両側副甲状腺を摘除 せざるをえなかったよらな症例をのぞいて, 臨床上問 題のあった症例は皆無である。 


\section{〔3〕症 例}

代表例として一次的に行なったものと，二次的に本 法を適用したもののそれぞれ一例つうつついて述べ る。

症例 1 Y.I., 52 才女性。入口部下 $3 \mathrm{~cm}$ におよぶ下咽 頭頸部食道癌。頸部U字型皮切でまず気管を胸骨上縁 で切断。前胸壁正中タテ皮切を追加し, 本術式によっ て, 右腕頭動脈をくぐらせてから永久気管瘦を造設。 ここで, われわれが頸部廊清と咽喉食摘を, 外科チー ムが開腹して有茎結腸の作成を同時に開始した。削除 した胸骨断端から用指剝離にて食道全拔去（図 7 )。 後綎隔経由有茎結腸 interp:sition で食道を再建した (図 8 )。術後 3 年を経過して再発なく健在。気管孔の 状態も良好である（図 9 )。

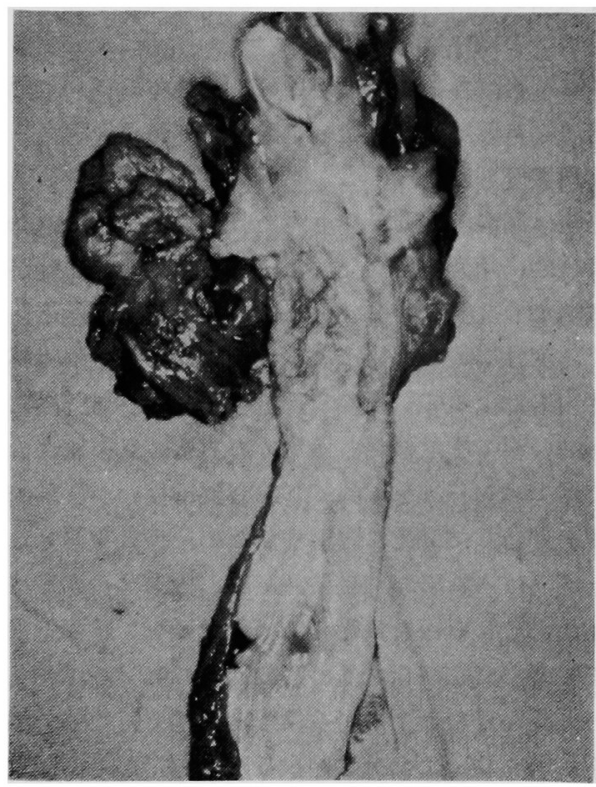

図 7 下咽頭・頚部食道癌症例。非開胸食道 全抜去と喉頭全摘並びに頸部廊清術施 行。

症例 2 H.Y., 63才男性。喉頭癌全摘後の stomal recurrence。気管孔そのものは正常で，おそらく傍気 管リンパ節転移巣からの腫大と思われた(図10)。本術 式により気管は $4 \mathrm{~cm}$ 切除, 食道壁へも浸潤あるため 非開胸食道全抜去(図11)。胃つり上げによる transposition で食道を再建した。術後気管内腔の痂皮形成が

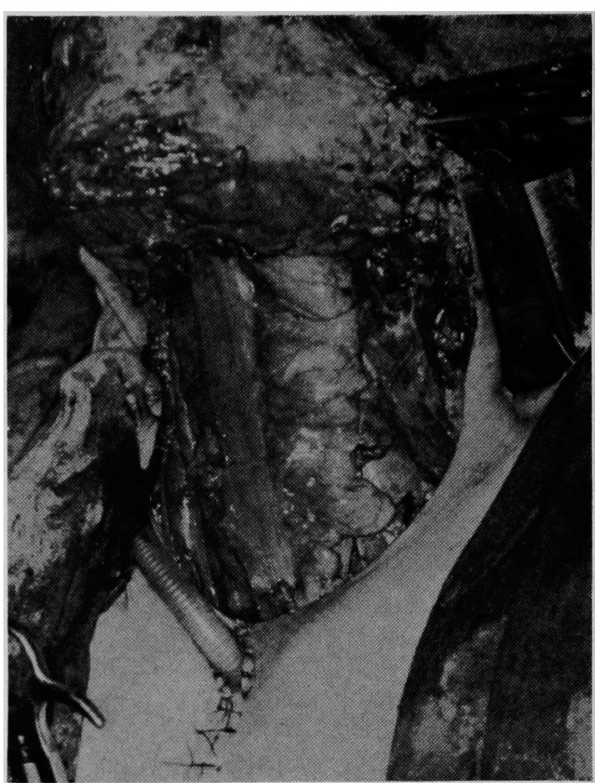

図 8 後縦隔経由, 有茎結腸 interpositioning に上る食道再建。

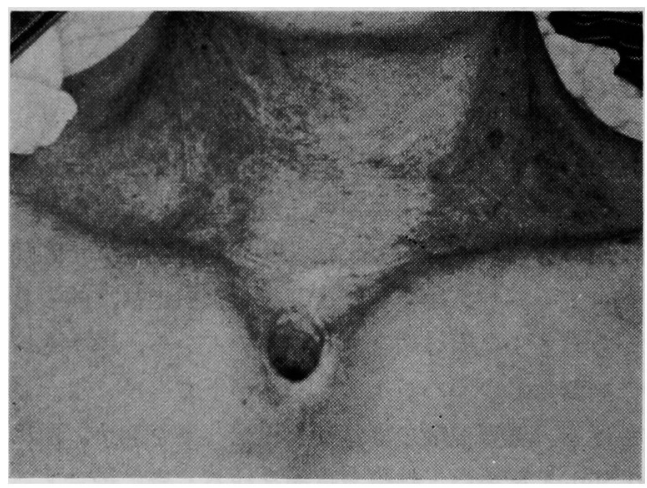

図 9 症例 1 の術後 3 年目の所見

多かったが，高湿度と軟こう塗布により解決。現在術 後 1 年で再発を認めず，順調に経過観察中である。

\section{[4]まめと}

頸部あるいは頸胸境界部の手術に際して, より広籁 用な気管切除が要求される場合, 胸骨の一部および鎖 骨骨頭を切除して前綖隔に達し，ここを経由して永久 気管瘦を造設する機会が多くなった。そこで, その基 本的術式について症例をあげて説明した。

御校閲下さった斎藤成司教授に哚謝すると共に, 臨 床例につき日夜御協力いただいている教室員各位に深 く感謝します。なお，本論文の要旨は第28回日本気管 


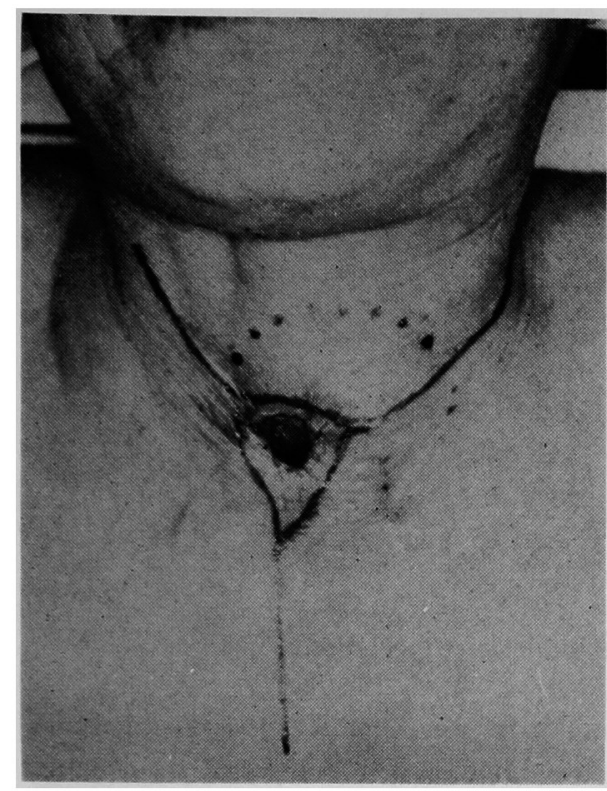

図10 喉頭全摘後の stomal recurrence 症例 皮切線を示す。点線は硬結部。

食道科学会総会にて報告した。

文献

1) Bardenheuer: Die Resektion des Manubrium Sterni. Deutsche Med. Wochenschr., 11, 688, 1885.

2 ) Waddell, W.R., et al.: A technique for subtotal excision of the trachea and establishment of a sternal tracheotomy. Ann. Surg., 149, 1, 1959.

3 ) Sisson, G.A.: Mediastinal dissection for recurrent cancer after laryngectomy. Laryngoscope, $72,1064,1962$.

4 ) Pressman, J.J. et al.: Dissection of the neck and mediastinum in continuity for carcinoma of

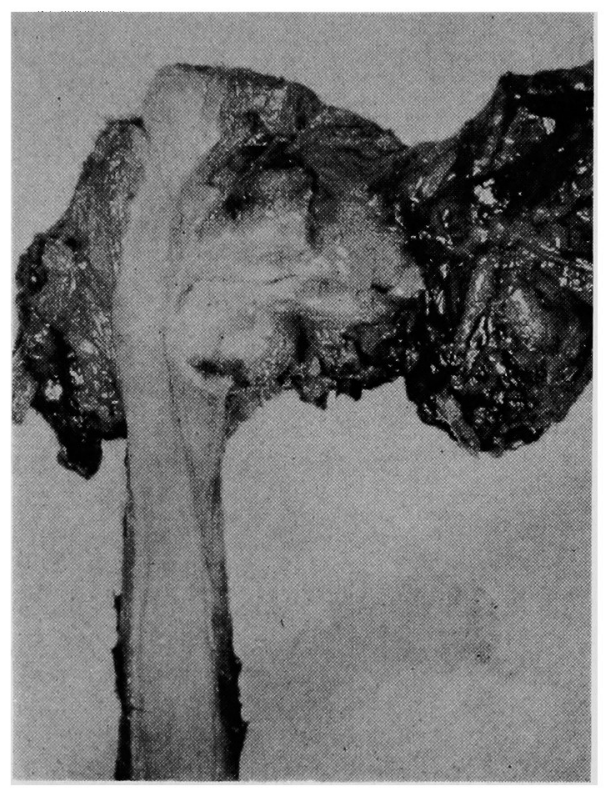

図11 頸部廊清および気管孔を含めて非開胸食道全抜 去。気管孔から入れた割面で食道壁へ浸潤がみ られる。

the head and neck. Laryngcsccpe, 74, 828, 1964.

5 ) Mcntg mery, W.W.: Surgery of the upper respiratory tract. Vol. 2. Lea \& Febiger, 1973.

6 ）行木英生, 他：気管孔狭窄に対する W.W. Montgomery 術式の経験。日気食会報，25，245，1974.

7 ）斎藤成司, 他：胸骨正中切開による繸隔廊清術の 経験, 日耳鼻会報, 72, 902, 1969.

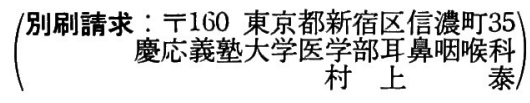

（投稿受付 1977 年 6 月10日） 